\title{
動吸振器を用いたエレベータ・ロープの横振動抑制
}

木村 弘之*1, 番匠 光平 ${ }^{* 2}$

\section{Suppression of transverse vibration of elevator rope using dynamic damper}

\author{
Hiroyuki KIMURA $^{* 1}$ and Kohei BANSHO ${ }^{* 2}$ \\ ${ }^{* 1}$ Graduate School of Science and Engineering for Research, Toyama University \\ 3190 Gofuku, Toyama-shi, Toyama, 930-8555, Japan \\ ${ }^{* 2}$ Graduate School of Science and Engineering for Education, Toyama University \\ 3190 Gofuku, Toyama-shi, Toyama, 930-8555, Japan
}

\section{Received 23 September 2014}

\begin{abstract}
An elevator rope for a high-rise building is forcibly excited by the displacements of the building induced by wind forces and/or by long-period ground motion. In high-rise building, the elevator rope may resonate with natural frequency of the building, and lateral vibration becomes large; hence, effective solution to reduce the rope displacement is demanded. In this paper, a method to suppress the rope displacement by using dynamic damper is proposed. Rope lateral vibration is controlled by fluctuating rope tension using up-and-down motion of this dynamic damper. Finite difference analyses of rope vibration with dynamic damper are performed to verify the validity of this method. Experiments involving forced vibration of a rope whose length is constant are also performed. The optimal natural frequency of this dynamic damper is about 2 times of the natural frequency of the rope lateral vibration. The rope sway can be reduced to about $1 / 2$, when the cage is stopped.
\end{abstract}

Key words : Elevator, Rope sway, Dynamic damper, Finite-difference method, Forced vibration

\section{1. 緒言}

超高層ビルに設置されているエレベータにおいては，地震時や強風時の建物摇れにより，エレベータ・ロープ の摇れが大きくなり, 昇降路内機器へ衝突したり絡まる可能性がある. このため, ビルの摇れに応じてエレベー タを減速したり，停止するなどの運行制限（管制運転）が行われている. しかし，エレベータの運転効率向上や 安全性確保の観点から，ロープ摇れの抑制が望まれている.

従来，このロープ摇れを抑制するためいくつかの研究が行われており，走行中のロープ長さの変化を考慮して ロープ摇れを制御する方法(大槻他，2002)，ロープの摇れを振れ止め枠等で拘束する方法(木村，中川，2005)，建 物の摇れに共振しないようにかご位置を移動させる方法(渡辺他，2007), 永久磁石の吸引力を利用してロープの 摇れを非接触で制御する方法(勝野他，2007)，コンペンシーブにダンパーを取り付け上下方向の振動に隇衰を加 えることでロープの摇れを抑える方法(中川，新井， 2012)等が提案されている. このうち，振れ止め枠を用いて ロープ摇れをある程度以上大きくならないようにする方法が実用化されているが，振れ止め枠に衝突するまでは 振動を抑制することはできない，また，かご位置を移動させる方法では，共振する階にはかごを停止させないこ とになり，一種の管制運転になってしまうという課題がある.

一方, 振動を低減させる方法として動吸振器があり, 図 1(a)に示すような 1 自由度系に対する動吸振器の最適 值（振動数比, 減衰比）は寸でに明らかにされている(背戸，2010など). しかし， ロープ摇れを動吸振器で低減 させようとすると, 動吸振器の振動によりロープ張力が変動し図 1(b)に示すように主系のばね定数が時々刻々変 化することになり，従来の設計手法はそのままでは適用できない，そこで本研究では，ロープと昇降路内機器と の距離が近い釣合いおもり側のロープを対象として，動吸振器によるロープ摇れの抑制方法について検討する.

\footnotetext{
No.14-00476 [DOI:10.1299/transjsme.14-00476], J-STAGE Advance Publication date : 20 January, 2015

${ }^{* 1}$ 正員, 富山大学 大学院理工学研究部 (工学) (T930-8555 富山県富山市五福 3190)

*2 富山大学 大学院理工学教育部 (現 : 日本電産 (株) )

E-mail of corresponding author: hkimura @eng.u-toyama.ac.jp
} 


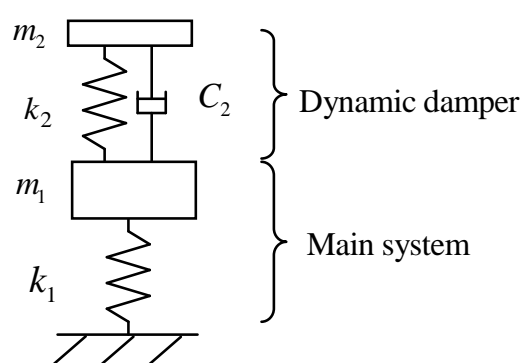

(a) Spring constant $k_{1}$ is constant

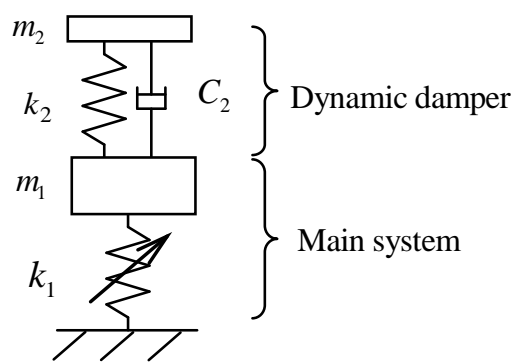

(b) Spring constant $k_{1}$ varies with time

Fig. 1 Vibration system with dynamic damper

\section{2. 解 析 方 法}

\section{$2 \cdot 1$ ロープの横振動解析}

エレベータのロープ構成及び解析モデルをそれぞれ図 2, 図 3 に示寸. かごと重量調整用の釣合いおもりとを メインロープで吊り，このメインロープと巻上機シーブとの摩擦によりエレベータを駆動している．また，かご 位置によるロープ張力の変動を抑えるためコンペンロープがかごと釣合いおもり下に配置されている．ビルが摇 れるとロープも摇れ昇降路内機器に衝突したり絡まる可能性がある. 本報では昇降路内機器との距離が近い釣合 いおもり側のメインロープ（図 2 で太く表示したロープ）を解析対象とする. 図 3(a)に示すようにロープ上端を 座標の原点とし，ロープ水平方向の変位を $u ，$ ロープ上端からの距離を $\mathrm{Z}$ とすると，長さの変化するロープの 運動方程式は次式で表される.

$$
\rho A\left(\frac{\partial}{\partial t}-V \frac{\partial}{\partial z}\right)^{2} u-\frac{\partial}{\partial z}\left(T \frac{\partial u}{\partial z}\right)+C\left(\frac{\partial}{\partial t}-V \frac{\partial}{\partial z}\right) u=0
$$

ここで, $\rho A$ はロープの単位長さ当りの質量, $V$ は速度, $T$ はロープ張力, $C$ はロープの単位長さ当りの減衰係 数 $\left(=2 \pi \zeta_{r} \sqrt{\rho A T} / L, \zeta_{r}\right.$ は減衰比 $)$ である.

今回の解析ではロープと昇降路機器との距離が近い釣合いおもり側のメインロープを解析対象とし，V=0 と して，式(1)の運動方程式を次式の差分近似(木村他，2008)を行うことにより数值解析を行う.

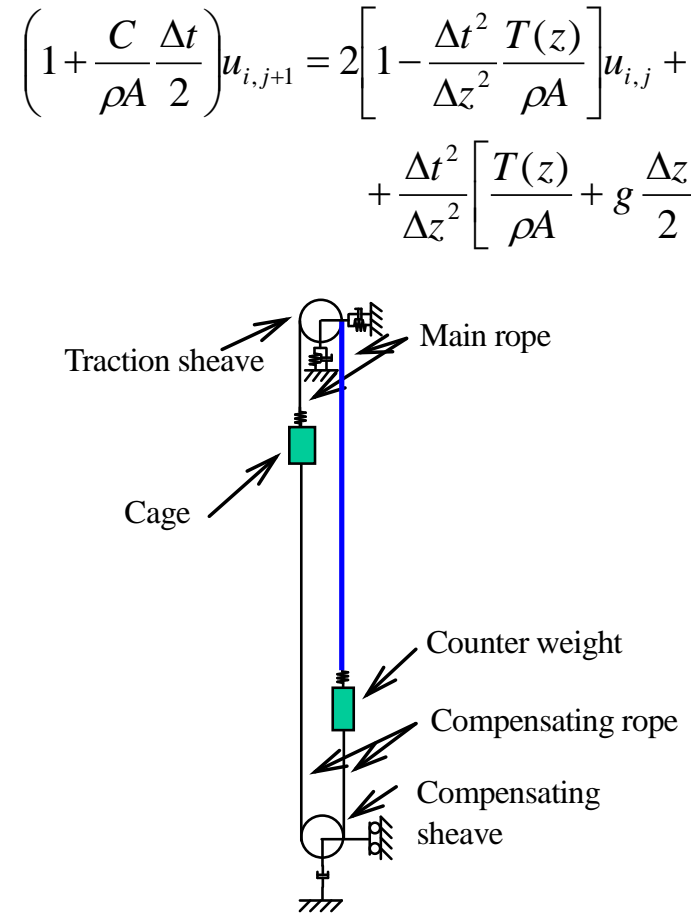

Fig. 2 Schematic diagram of elevator rope system 
ここで, $\Delta t$ は時間刻み, $\Delta z$ は分割したロープ要素の長さ, $u$ はロープ水平方向変位, 添字 $i, j$ はそれぞれ空 間座標，時間座標における格子点の番号， $g$ は重力加速度を表している.

\section{$2 \cdot 2$ 上下方向の振動解析}

図 3(b)は釣合いおもりの一部を動吸振器として用いたモデル図である．かご質量と釣合わせるため，図中の $m_{1}$

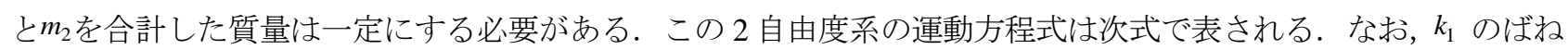
は，ロープと釣合いおもりとの間に設置されているばねをモデル化したものである.

$$
\left[\begin{array}{cc}
m_{1} & 0 \\
0 & m_{2}
\end{array}\right]\left\{\begin{array}{l}
\ddot{x}_{1} \\
\ddot{x}_{2}
\end{array}\right\}+\left[\begin{array}{cc}
c_{2} & -c_{2} \\
-c_{2} & c_{2}
\end{array}\right]\left\{\begin{array}{l}
\dot{x}_{1} \\
\dot{x}_{2}
\end{array}\right\}+\left[\begin{array}{cc}
k_{1}+k_{2} & -k_{2} \\
-k_{2} & k_{2}
\end{array}\right]\left\{\begin{array}{l}
x_{1} \\
x_{2}
\end{array}\right\}=\left\{\begin{array}{c}
k_{1} v \\
0
\end{array}\right\}
$$

ここで，ロープ下端の上下動 $v$ は式(2)の計算結果 $u_{i}$ をもとに，三平方の定理を用いて計算する.

$$
v=\sum_{i=1}^{n}\left(\sqrt{\Delta z^{2}+\left(u_{i}-u_{i-1}\right)^{2}}-\Delta z\right)
$$

おもりには，ロープ変位による上下動 $v$ が入力される. 一方，おもりの上下動がロープ側へは張力変動となっ てフィードバックされる. ロープ張力は動吸振器の上下動に起因する力 $k_{1}\left(v-x_{1}\right)$ を考慮して次式で表される.

$$
T=\left(m_{1}+m_{2}\right) g+\rho A g(L-z)+k_{1}\left(v-x_{1}\right)
$$

各時刻ごとに式(5)を用いて張力の変化をロープ摇れの解析にフィードバックする. また，時刻歴応答解析には ニューマーク $\beta$ 法を用いる.

\section{$2 \cdot 3$ 解析条件}

数值解析に用いたロープ等の諸元を表 1 に示寸. ケース 1 は昇降行程 $200 \mathrm{~m}$ クラスの実機エレベータを想定し ている. ケース 2 はロープ張力一様でロープ下端と釣合いおもり間を剛にした条件である. ケース 3 は 3 章に示 寸実験モデルの条件である. ロープ上端を水平方向に正弦波加振した場合の応答を 2.1 節, 2.2 節で示した方法で 数值解析を行う. なお，釣合いおもり十動吸振器の質量 $\left(m_{1}+m_{2}\right)$ は，かご質量と釣合わせるため一定とする.

Table 1 Simulation parameters

\begin{tabular}{|l|c|c|c|}
\hline & Case 1 & Case 2 & Case 3 \\
\hline Rope diameter $[\mathrm{mm}]$ & 20.0 & 20.0 & 1.5 \\
\hline Density per unit length $\rho \mathrm{A}[\mathrm{kg} / \mathrm{m}]$ & 1.7 & 1.7 & 0.009 \\
\hline Damping ratio of rope $\zeta_{r}$ & 0.002 & 0.002 & 0.0148 \\
\hline Rope length $L[\mathrm{~m}]$ & 200 & 200 & $1.6-2.3$ \\
\hline Excitation displacement $u_{0}\left[\mathrm{~mm}_{0-\mathrm{p}}\right]$ & $1.0-150.0$ & $1.0-150.0$ & 2.0 \\
\hline Mass $m_{1}+m_{2}[\mathrm{~kg}]$ & 1300 & 1300 & 0.132 \\
\hline Mass ratio $m_{2} / m_{1}$ & $0,0.1,0.2,0.3,0.4$ & $0.1,0.2,0.3$, & $0,0.4$ \\
\hline Spring constant $k_{1}[\mathrm{~N} / \mathrm{m}]$ & $8.35 \times 10^{4}$ & 0.4 & $8.35 \times 10^{2}$ \\
\hline Damping ratio of dynamic damper & $0-0.15$ & $8.35 \times 10^{7}$ & 0.023 \\
$\zeta_{2}=C_{2} /\left(2 \sqrt{m_{2} k_{2}}\right)$ & & 0.02 & \\
\hline Rope tension $T$ & $T_{0}=\left(m_{1}+m_{2}\right) g+\rho A g L / 2$ & $\left(m_{1}+m_{2}\right) g$ & $\left(m_{1}+m_{2}\right) g+\rho A g(L-z)$ \\
& $T=T_{0}+\rho A g(L / 2-z)+k_{1}\left(v-x_{1}\right)$ & $+k_{1}\left(v-x_{1}\right)$ & $+k_{1}\left(v-x_{1}\right)$ \\
\hline
\end{tabular}




\section{3. 実験方法}

\section{$3 \cdot 1$ 実験装置}

動吸振器を用いてロープの横振動を抑制できるか調べるため，モデル実験を行う．実験装置を図 4 に示す．ロ 一プ上端を電磁加振器により水平方向に正弦波加振でき，かごモデルはレールに沿って鉛直方向のみ移動可能で ある. 実験装置の諸元を表 2 に示す．かごモデルと動吸振器の質量は粘土の量により調整する.

\section{$3 \cdot 2$ ロープ及び動吸振器の振動特性}

ロープ中央を引張った後に解放し，その後の自由振動をビデオカメラを用い，240フレーム/秒で撮影する.

撮影した映像を Adobe Premiere Elements 2.0 により編集し，計測ソフトMoveTr2D を用いて画像解析を行う。これ により得られる自由振動波形から，ロープの減衰比と固有振動数を求める. また，片側におもりを付けた動吸振 器単体の中央を固定し, おもりを自由振動させることで, 減衰比と固有振動数を求める.

\section{$3 \cdot 3$ ロープ加振試験}

実験装置上部の加振器により, 加振振幅及び加振振動数一定で加振する. ロープ長は共振する長さを中心に任 意の長さで実験を行う．加振中のロープ摇れをビデオ撮影した後, 画像解析により得られる時刻歴波形から最大 振幅を求める．動吸振器なしの場合と動吸振器ありの場合の 2 ケースについて実験を行う.

なお，特にロープ摇れが大きくなると，ロープが加振方向と直行する方向にも摇れ始め，回転運動することが あったため, ロープから $1.5 \mathrm{~mm}$ の距離に加振方向と直行する方向への摇れを拘束する部材を取り付けた条件でも 実験を行った.

Table 2 Experiment conditions

\begin{tabular}{|l|c|}
\hline Rope diameter $[\mathrm{mm}]$ & 1.5 \\
\hline Density per unit length $\rho \mathrm{A}[\mathrm{kg} / \mathrm{m}]$ & 0.009 \\
\hline Rope length $L[\mathrm{~mm}]$ & $1600-2300$ \\
\hline Excitation displacement $u_{0}\left[\mathrm{~mm}_{0-\mathrm{p}}\right]$ & 2.0 \\
\hline Frequency $f[\mathrm{~Hz}]$ & $2.8-3.4$ \\
\hline Mass $m_{1}+m_{2}[\mathrm{~kg}]$ & 0.132 \\
\hline Mass ratio $\quad \alpha=m_{2} / m_{1}$ & $0,0.4$ \\
\hline
\end{tabular}

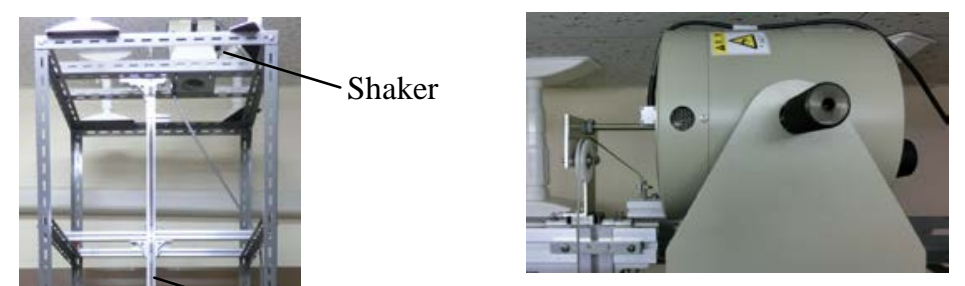

(b) Shaker

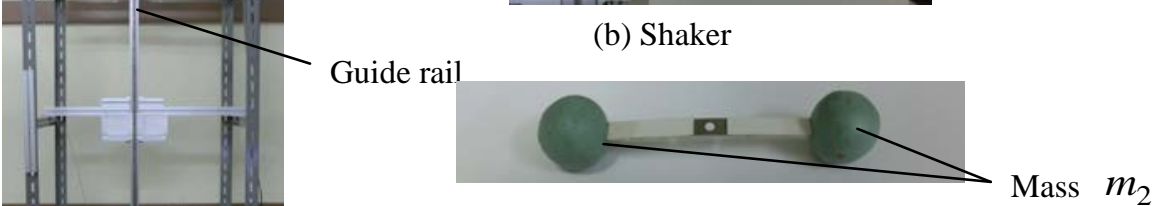

(c) Dynamic damper

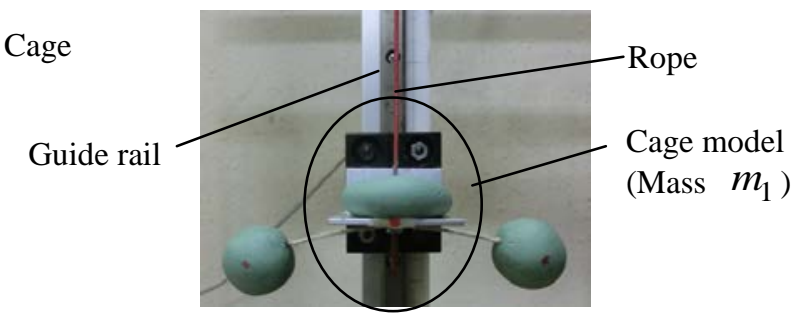

(d) Dynamic damper attached to cage model

(a) Overview of experimental set-up

Fig. 4 Experimental set-up 


\section{4. 結果及び考察}

\section{$4 \cdot 1$ 周波数応答特性（動吸振器がない場合）}

動吸振器が無い場合についてのロープの周波数応答特性を計算した. 加振振幅 $u_{0}$ をパラメータとした結果の一 例を図 5 に示す. 加振振動数はロープの固有振動数（ $f_{n 0}=0.23 \mathrm{~Hz} ）$ で割って無次元化している. 加振振幅と周 波数応答の最大值との関係を図 6 に示寸。これらの図から，加振振幅が小さい場合には応答倍率の最大值は $N_{\max }=1 /\left(\pi \times \zeta_{r}\right) \simeq 159.2$ 程度であるが, 加振振幅が大きくなると動吸振器が無い場合でも応答倍率は低下してい ることが分かる．この原因としては，動吸振器が無くても釣合いおもりの上下動によりロープ張力が変動するた めと考えられる．なお，張力変動を考慮しなければこのような非線形性は発生しない.

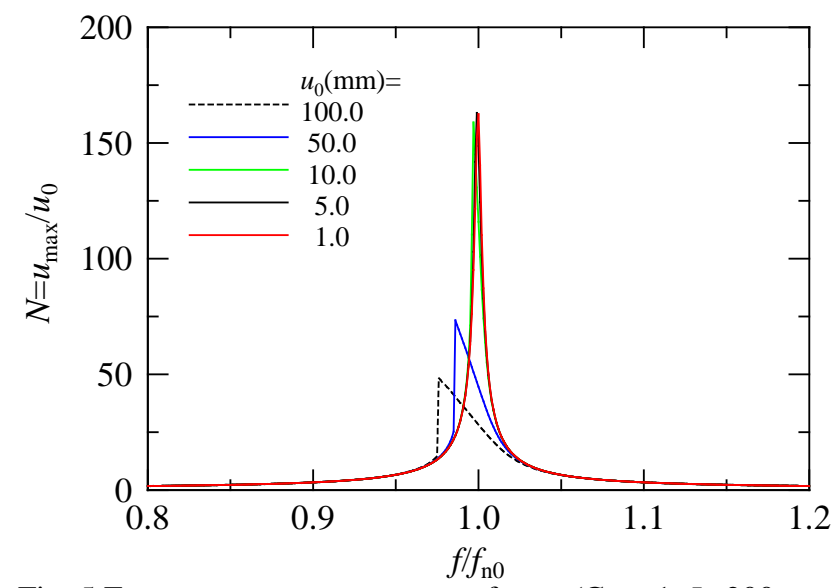

Fig. 5 Frequency response curves of rope (Case 1, $L=200 \mathrm{~m}$, without dynamic damper). Maximum rope deflection and frequency are normalized by the input amplitude and the natural frequency of the rope, respectively.

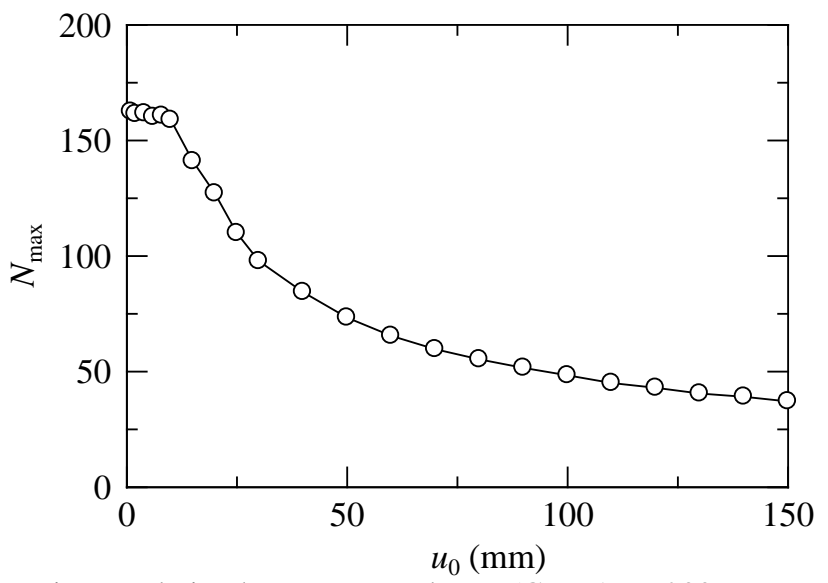

Fig. 6 Relation between $u_{0}$ and $N_{\max }$ (Case $1, L=200 \mathrm{~m}$, without dynamic damper). The amplitude magnification factor $N_{\max }$ decreases with the increase in input displacement $u_{0}$.

\section{$4 \cdot 2$ 周波数応答特性（動吸振器がある場合）}

釣合いおもりと動吸振器の質量比 $\alpha\left(=m_{2} / m_{1}\right)$, 動吸振器の減衰比 $\zeta_{2}$, ロープの固有振動数と動吸振器の固有 振動数との比 $f_{n 2} /\left(2 f_{n 0}\right)$ をパラメータとして, ロープの周波数応答特性を計算した. 加振振幅 $u_{0}=100 \mathrm{~mm}$ とし た場合の結果の一例を図 7 に示す．図 7(a)はロープ最大変位, 図 7(b)は動吸振器の相対変位をそれぞれ加振振幅 で割って無次元化している. なお， $f_{n 2} /\left(2 f_{n 0}\right)$ をパラメータとしたのは，ロープが水平方向に 1 周期の振動をす ると, 上下方向に 2 回運動を行うためである. 図 8 には動吸振器の減衰比をパラメータとした結果を示す.

これらの図から, ロープの固有振動数と動吸振器の固有振動数との比 $f_{n 2} /\left(2 f_{n 0}\right)$ が 1.0 付近で, 動吸振器の減 衰比 $\zeta_{2}$ が 0.02 付近で応答が小さくなっていることが分かる.

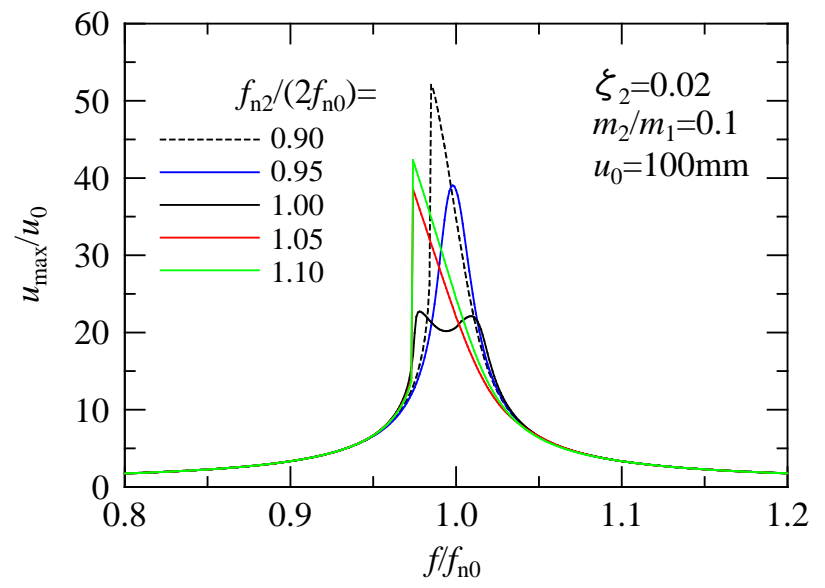

(a) $u_{\max } / u_{0}$

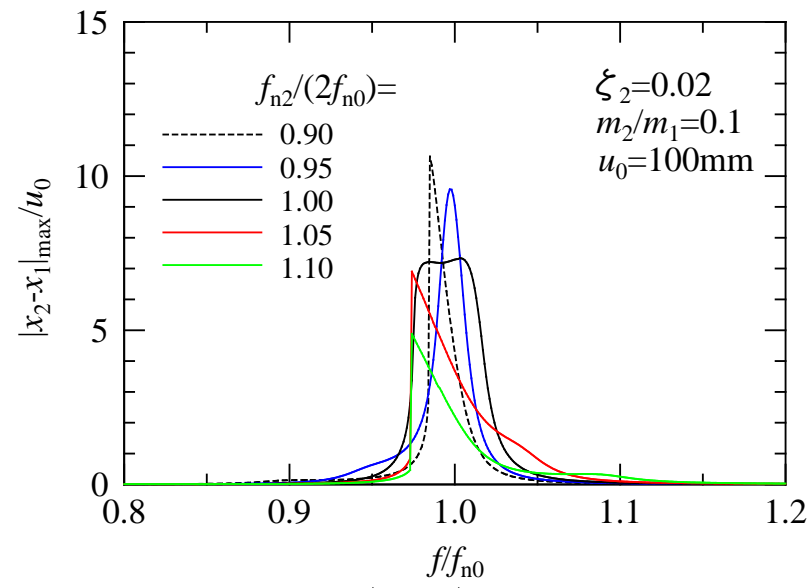

(b) $\left|x_{2}-x_{1}\right|_{\max } / u_{0}$

Fig. 7 Frequency response curves of rope with dynamic damper (Case $1, L=200 \mathrm{~m}, u_{0}=100 \mathrm{~mm}$ ). The amplitude magnification factor is smaller in the case of frequency ratio 1.00 than the other cases. 


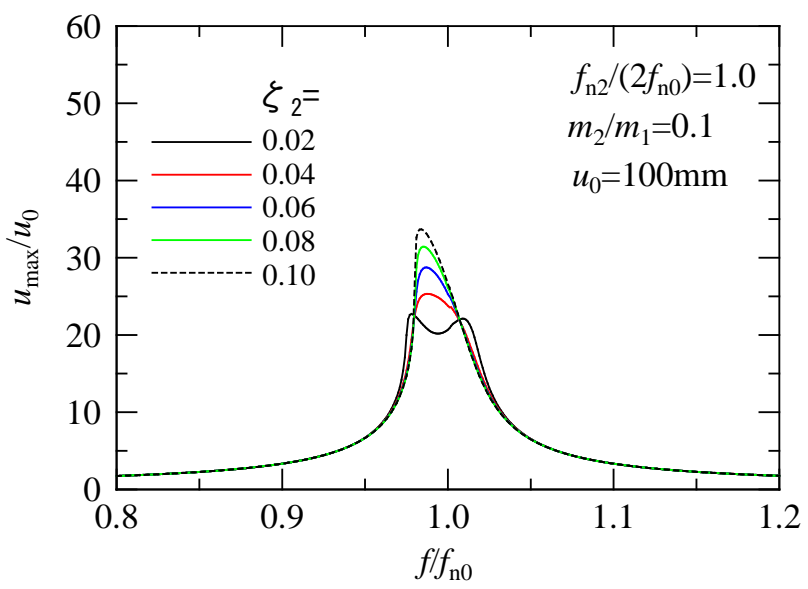

(a) $u_{\max } / u_{0}$

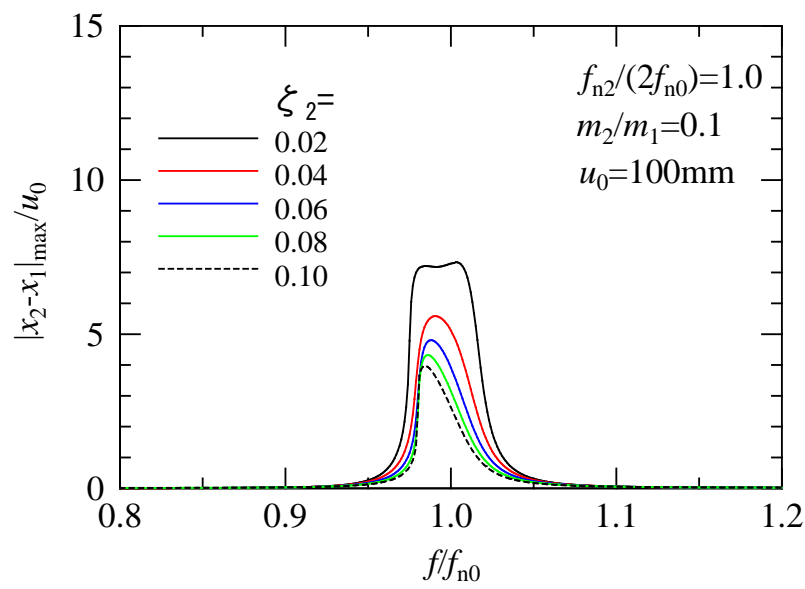

(b) $\left|x_{2}-x_{1}\right|_{\max } / u_{0}$

Fig. 8 Frequency response curves of rope with dynamic damper (Case $1, L=200 \mathrm{~m}, u_{0}=100 \mathrm{~mm}$ ). The amplitude magnification factor is smaller in the case of damping factor 0.02 than the other cases.

\section{4-3 ロープ張力の変動}

図 7(a)で，ロープの固有振動数と動吸振器の固有振動数との比 $f_{n 2} /\left(2 f_{n 0}\right)$ が 1.0 で，加振振動数とロープの固 有振動数の比が 1.0 の場合のロープ中央での変位と張力についての時刻歴波形の一例を図 9 に示す. この図から ロープ変位の絶対值が増加する間（A-B 間）はロープ張力が増加し，ロープ変位の絶対值が減少する間（B-C 間） はロープ張力も減少していることが分かる. また, 加振振幅が $100 \mathrm{~mm}$ で質量比が 0.1 の場合, ロープ張力は土6\% の範囲で変動していることが分かる. また, 加振振幅 $u_{0}$ と張力変動との関係を図 10 に示す. この図から, 加振

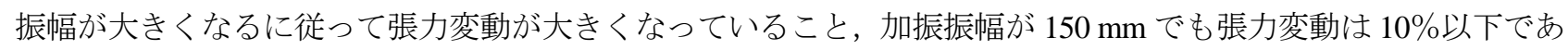
ることが分かる。
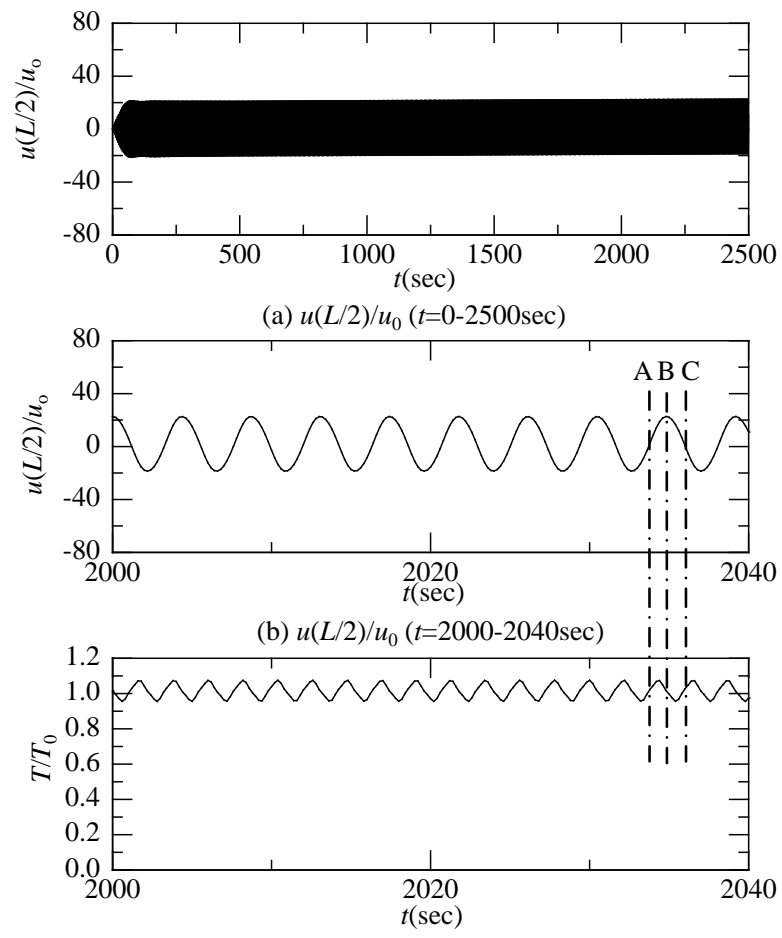

(c) $T / T_{0}(t=2000-2040 \mathrm{sec})$

Fig. 9 Time history of rope deflection and rope tension

(Case $1, L=200 \mathrm{~m}, f / f_{n 0}=1.0, m_{2} / m_{1}=0.1, u_{0}=100 \mathrm{~mm}$, $\left.z=L / 2, \zeta_{2}=0.02\right)$. When the absolute value of rope displacement increases, rope tension also increases.

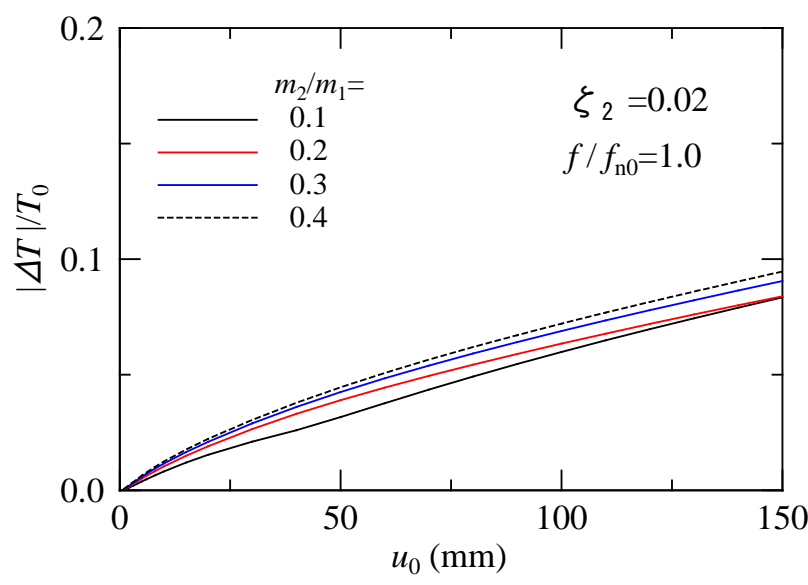

Fig. 10 Relation between $u_{0}$ and tension fluctuation

(Case $1, L=200 \mathrm{~m}$ ). Tension fluctuation is large as excitation amplitude becomes large, and is $10 \%$ or less when excitation amplitude is $150 \mathrm{~mm}$. 


\section{$4 \cdot 4$ 振動数比, 減衰比の最適値}

動吸振器の減衰比を一定にした場合の振動数比 $f_{n 2} /\left(2 f_{n 0}\right)$ と応答倍率の最大值 $N_{\max }$ との関係を図 $11(\mathrm{a})$, 振動 数比を一定にした場合の減衰比 $\zeta_{2}$ と応答倍率の最大值 $N_{\max }$ との関係を図 11(b)に示寸. これらの図から, 動吸振 器の固有振動数は，質量比により多少変化するが，概ねロープの固有振動数の 2 倍程度が最適であることが分か る. また, 動吸振器の減衰比の最適值は, 質量比が増加寸るにつれて大きくなっていることが分かる. なお, 図

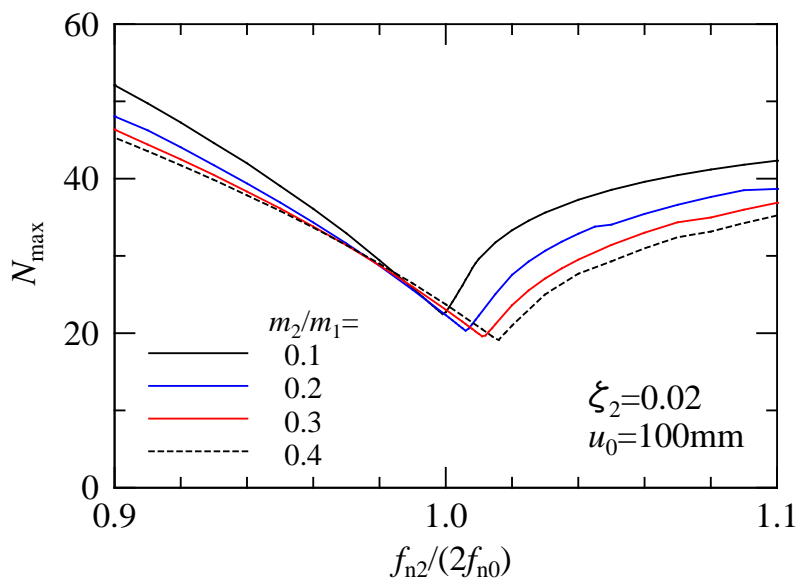

(a) Effect of frequency ratio on amplification factor

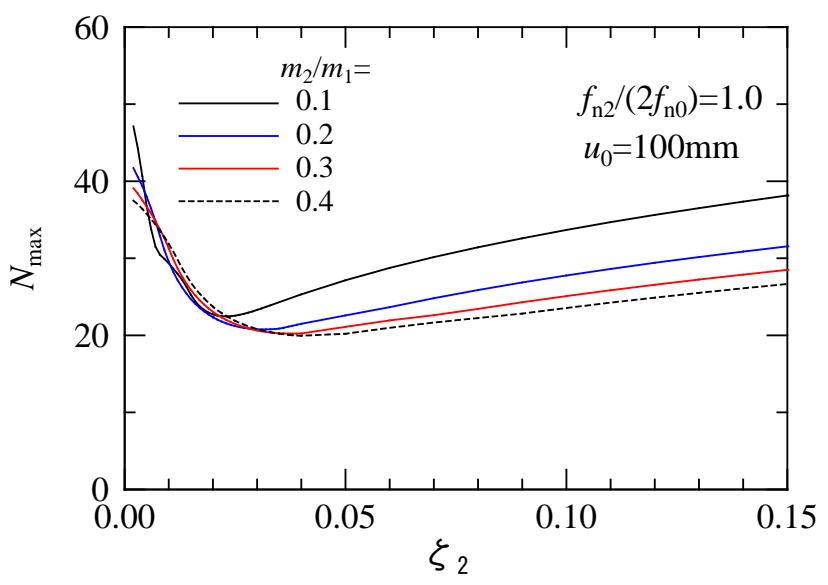

(b) Effect of damping ratio on amplification factor

Fig. 11 Optimal parameters of dynamic damper (Case $1, L=200 \mathrm{~m}, u_{0}=100 \mathrm{~mm}$ ). Frequency ratio and damping ratio are changed, respectively.

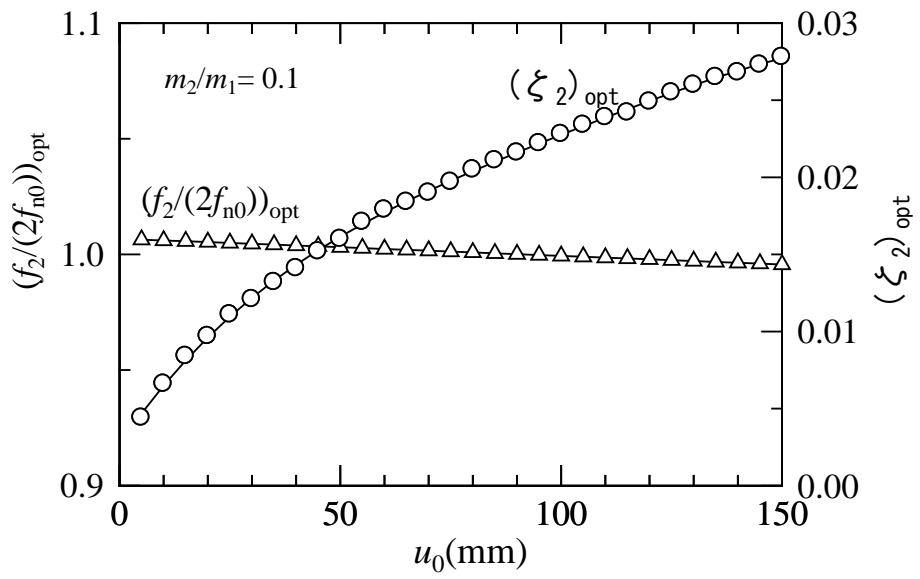

Fig. 12 Optimal parameters of dynamic damper (Case 1, $L=200 \mathrm{~m}$ ). Frequency ratio and damping ratio are changed simultaneously.

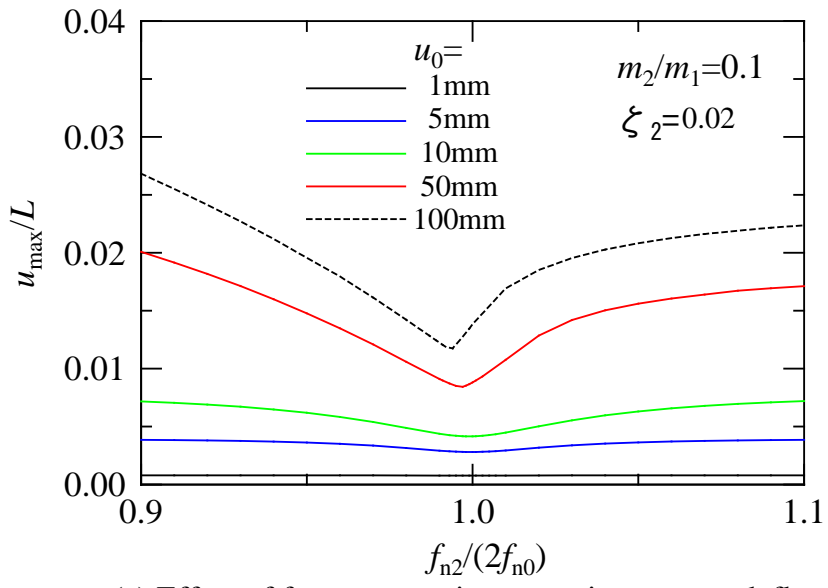

(a) Effect of frequency ratio on maximum rope deflection

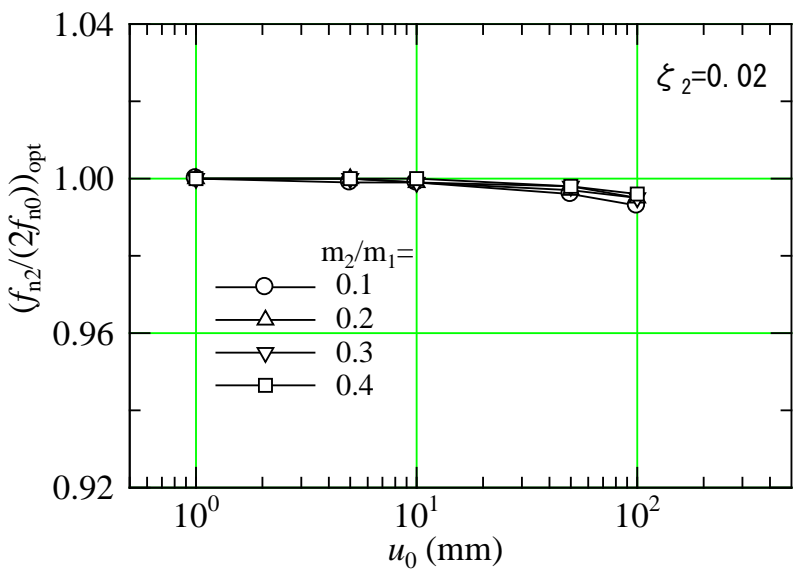

(b) Effect of $u_{0}$ on optimal frequency ratio

Fig. 13 Optimal parameters of dynamic damper (Case 2, $L=200 \mathrm{~m}$ ). These figures show that the optimal value of frequency ratio $f_{n 2} /\left(2 f_{n 0}\right)$ is 1.0 on ideal condition(Case 2$)$. 
11(b)から動吸振器の減衰比 $\zeta_{2}$ が小さくなり 0 に近づくとロープの摇れが大きくなることも分かる.

動吸振器の固有振動数と減衰比をパラメータとして変化させた場合に応答倍率が最小となる最適条件を図 12 に示す.この図からも，動吸振器の固有振動数は，通常の動吸振器（図 1(a)）のように質量比の影響を受けず概 ねロープの固有振動数の 2 倍程度が最適であることが分かる。また加振振幅が $100 \mathrm{~mm}$ の場合でも, 最適な振動 数比の変化は $1 \%$ 程度であることが分かる.さらに, 減衰比の最適值は加振振幅に依存することが分かる.

次に, 同様の解析をケース 2（ロープ自重分を無視し, 張力一様でばねが剛）の条件で行った. 動吸振器の減 衰比を一定にした場合の振動数比 $f_{n 2} /\left(2 f_{n 0}\right)$ とロープ最大変位 $u_{\max }$ との関係を図 $13(\mathrm{a})$, 加振振幅 $u_{0}$ と振動数比 の最適值との関係を図 13(b)に示す.これらの図から, 張力一様で加振振幅が小さい場合には最適な振動数比 $f_{n 2} /\left(2 f_{n 0}\right)$ は 1 であることが分かる.

\section{4 - 5 加振振幅の影響}

図 14 にロープに入力する強制変位の振幅を 1～150mm まで変化させた場合の振幅と応答倍率の関係を示す. この図から，加振振幅が $10 \mathrm{~mm}$ 程度以上であれば，ロープ最大変位を $1 / 2$ 程度まで低減でき動吸振器による振動 抑制効果があることが分かる．加振振幅が $10 \mathrm{~mm}$ 程度より小さい領域では，ロープ最大变位を $1 / 2$ 程度まで低減 できてはいないが，ロープの応答が元々小さいことから，実用上は問題ないと考えられる. 加振振幅とロープ下 端の上下動とは比例関係ではなく, 加振振幅が大きくなると上下動がより大きくなるという非線形性がこの原因 であり，加振振幅が小さい領域では上下動による張力変動がより小さくなるためと考えられる.

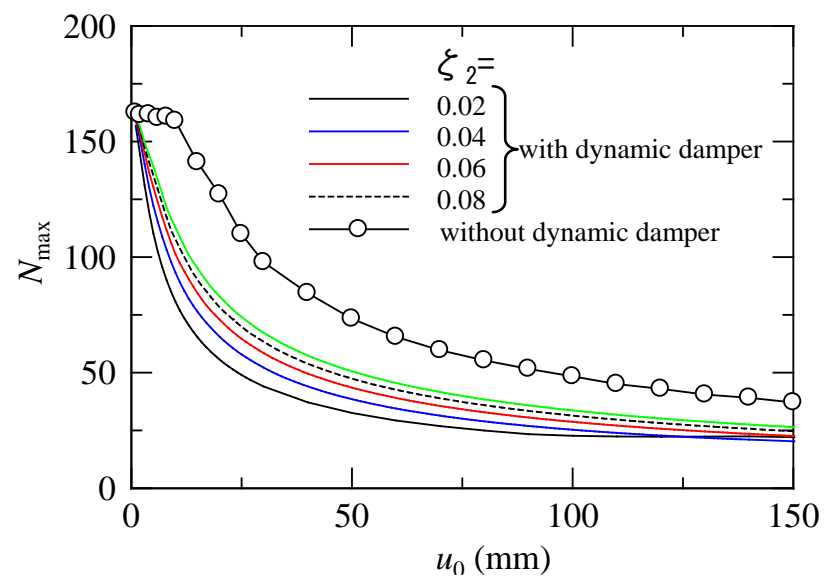

Fig. 14 Relation between $u_{0}$ and $N_{\max }$ (Case $\left.1, L=200 \mathrm{~m}, m_{2} / m_{1}=0.1, f_{n 2} /\left(2 f_{n 0}\right)=1.0\right)$. By using dynamic damper, the amplitude magnification factor becomes half of that without dynamic damper, in the case of damping factor 0.02.

\section{4 - 6 張力のばらつきの影響}

実際のエレベータは 10 本程度のエレベータ・ロープによって吊っているため張力にばらつきが発生するが, 設

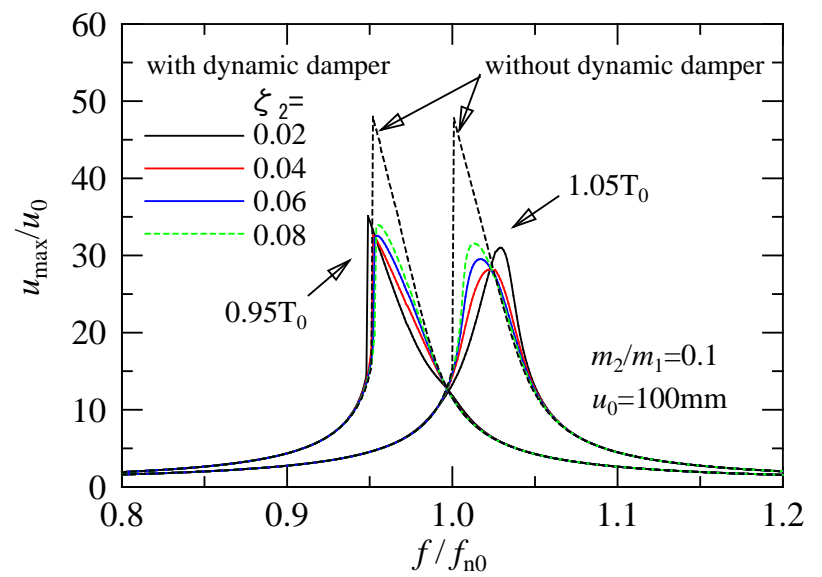

Fig.15 Frequency response curves of rope with/without dynamic damper (Case $1, L=200 \mathrm{~m}$ ). Calculated results of amplitude magnification factor without dynamic damper are plotted with dotted (black) curves. 
定值の $\pm 5 \%$ 以内に調整されている. 図 15 は, 動吸振器の振動数比 $f_{n 2} /\left(2 f_{n 0}\right)$ を 1.0 に設定した後にロープ張力 が設定值から 5 \% 変化した場合のロープの周波数応答特性である. この図からロープ張力が $\pm 5 \%$ 変化しても, 動 吸振器の効果は低下寸るものの, 減衰比が適切であればロープ最大変位は $2 / 3$ 程度まで低減できることが分かる.

\section{$4 \cdot 7$ 実験結果との比較}

図 16 にロープ上端を正弦波加振した場合のロープ長さと応答倍率との関係を示す．図中の○印で示した実験 結果においては, 共振点付近ではロープが加振直角方向にも振動し, 動吸振器が十分機能していないことがある. この原因は，ロープが回転運動をすることで動吸振器が上下動せずその効果を発揮できないためと考えられる.
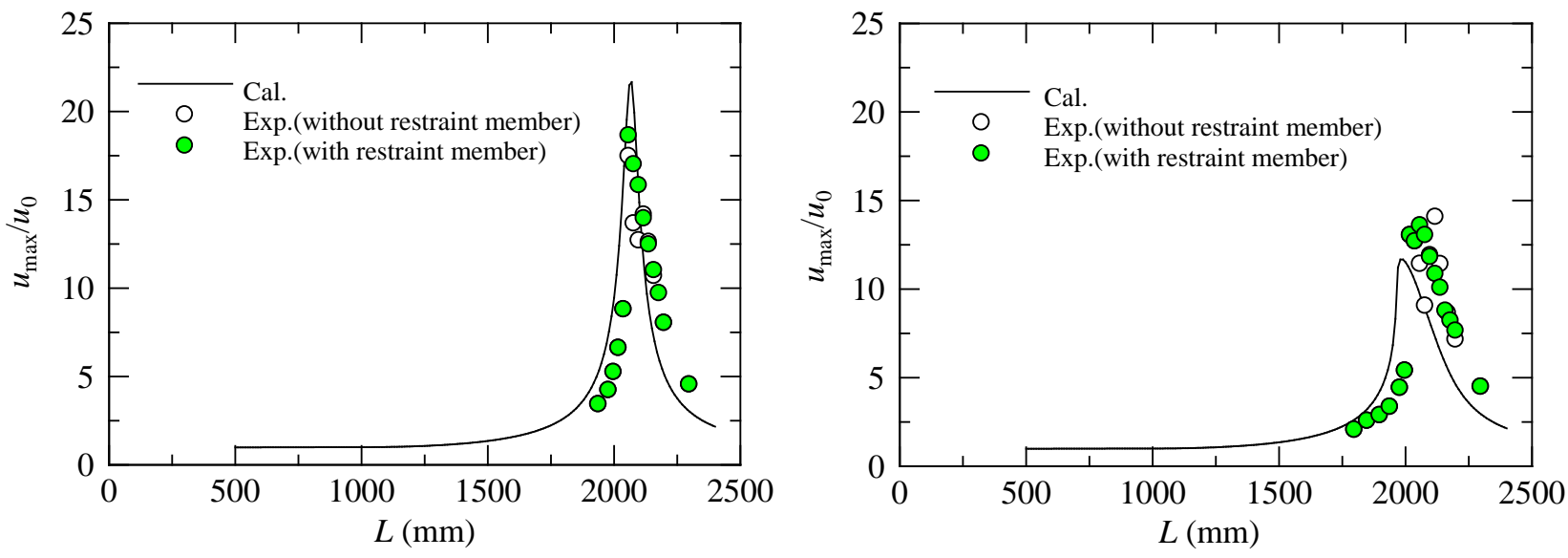

(a) $f=3.0 \mathrm{~Hz}$ (without dynamic damper)

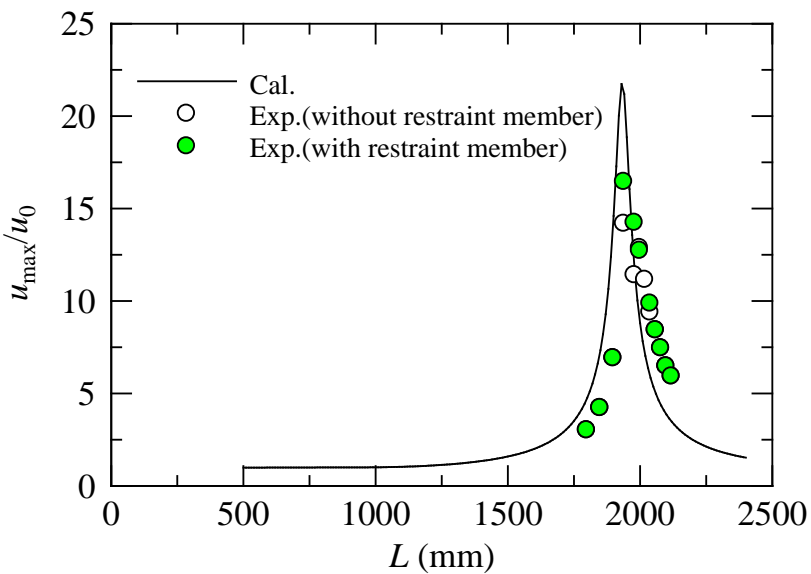

(b) $f=3.0 \mathrm{~Hz}:\left(f_{\mathrm{n} 2} /(2 f)=1.053\right)$ (with dynamic damper)

(c) $f=3.2 \mathrm{~Hz}$ (without dynamic damper)

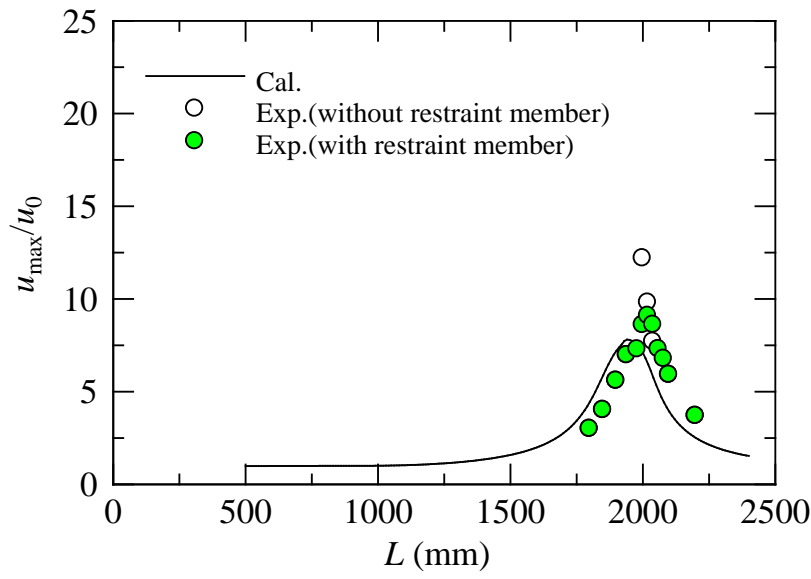

(d) $f=3.2 \mathrm{~Hz}:\left(f_{n 2} /(2 f)=0.988\right)$ (with dynamic damper)
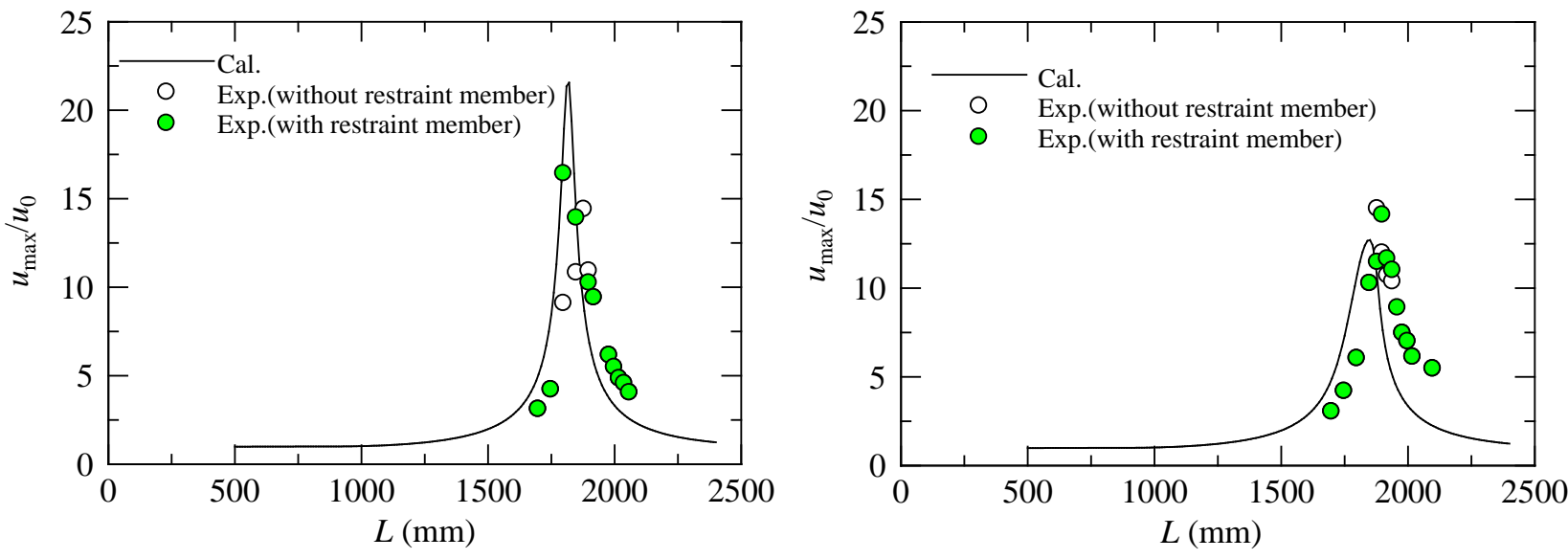

(e) $f=3.4 \mathrm{~Hz}$ (without dynamic damper)

(f) $f=3.4 \mathrm{~Hz}:\left(f_{n 2} /(2 f)=0.929\right)$ (with dynamic damper)

Fig.16 Relation between rope length and maximum rope deflection (Case 3, $u_{0}=2.0 \mathrm{~mm}$ ). Experimental results without restraint member and with restraint member are plotted white round marks and green round marks, respectively. 
図中の○印で示した実験結果においては，加振直角方向への振動が成長しないようにロープとギャップ $1.5 \mathrm{~mm}$ の位置に変位拘束部材を配置して加振試験を行った。これらの図から動吸振器がない場合には, 応答倍率の最大 值は $u_{\max } / u_{0}=1 /\left(\pi \times \zeta_{r}\right) \simeq 21.5$ となっていること, 動吸振器がある場合には約 $1 / 2$ 程度に低減できていることが 分かる．なお，ロープ及び動吸振器の減衰比は自由振動試験によって測定した值（表 $1: \zeta_{r}=0.0148 ， \zeta_{2}=$ 0.023 ）を用いた。 また, 動吸振器の固有振動数は $f_{n 2}=6.32 \mathrm{~Hz}$ であった.

図 17 に振動数比と各加振振動数における応答倍率の最大值との関係を示す. 数值解析の結果, 振動数の比が 1 付近で動吸振器が最も効いていることが分かる. また, 変位拘束部材を用いてロープの回転を防止した方が数值 解析結果に近い結果が得られた.

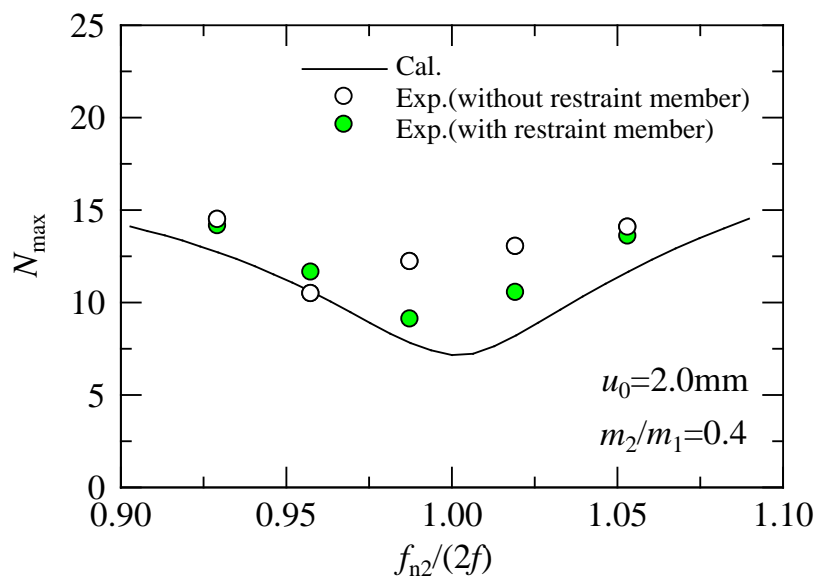

Fig.17 Relation between frequency ratio and maximum rope deflection (Case 3).

Dynamic damper is most effective when frequency ratio is around 1.0.

\section{5. 結言}

地震時や強風時のエレベータ・ロープの横振動抑制を目的として，動吸振器による振動抑制方法を提案し，ロ 一プが摇れ易い階付近にかごが停止している場合の釣合いおもり側のメインロープを対象として数值解析及びモ デル実験を行った. 得られた結果を要約して以下に示す.

（1）動吸振器を用いない場合でもおもりの上下動による張力変動により, 加振振幅の増加とともに応答倍率が 低減することを数值解析により示した.

(2) 動吸振器の固有振動数は, 概ねロープ横振動の固有振動数の 2 倍程度が最適であることを確認した.また, 動吸振器の減衰比の最適值は，質量比が増加するとともに大きくなる傾向があることを確認した.

（3）数值解析の結果，動吸振器を用いることでかごが停止している場合には，加振振幅が小さい場合を除き， ロープ摇れを $1 / 2$ 程度まで抑制できることを確認した.

（4）張力が $5 \%$ 変化すると, 動吸振器の効果が低下すること, 質量比が 0.1 の場合 $2 / 3$ 程度の低減となること を示した.

（5）モデル実験においても，ロープの振動方向を 1 方向に制限できれば，動吸振器によりロープ摇れを $1 / 2$ 程 度に抑制できることを確認した。

\section{文献}

勝野友介，松久寛，宇津野秀夫，山田啓介，澤田勝利，永久磁石の吸引力を利用したロープの非接触制振一モー

ド解析と伝達行列解析の対比一, Dynamics and Deign Conference 2007, No.07-8 (2007), (CD-ROM 論文集，論文 No. 426),pp.1-6.

木村弘之, 中川俊明, 振れ止め枠を有するエレベータ・ロープの横振動解析, 日本機械学会論文集 C 編, Vol. 71,

No. 702 (2005), pp. 442-447.

木村弘之, 飯島智樹, 松尾繁憲, 藤田善昭, エレベータ・ロープの横振動解析 (実験結果と解析結果の比較), 日 
本機械学会論文集 C 編，Vol. 74, No. 737 (2008), pp.31-36.

中川淳一, 新井晋治, コンペンセーションシーブの抑制によるエレベータロープの制振, 日本機械学会 昇降機・ 遊戯施設等の最近の技術と進歩＼cjkstart技術講演会論文集，No. 11-94 (2012), pp. 23-26.

大槻真嗣，吉田和夫，永田晃則，木村弘之，中川俊明，超高層ビルのエレベータ・ロープ横振動抑制（時変柔軟 システムへの非定常最適制御の適用），日本機械学会論文集 C 編, Vol. 68, No.676 (2002), pp. 3589-3596.

背戸一登, 動吸振器とその応用(2010), pp.1-56, コロナ社.

渡辺誠治, 西田隆雄, 山根尚志, 長周期地震動におけるエレベーターロープの挙動解析, 日本機械学会 昇降機・ 遊戯施設等の最近の技術と進歩＼cjkstart技術講演会論文集，No. 06-67 (2007), pp. 15-18.

\section{References}

Katsuno, Y., Matsuhisa, H., Utsuno, H., Yamada, K. and Sawada, K., Non-contact vibration control of elevator rope using magnetic force -Comparison between modal analysis and transfer matrix analysis-, Proceeding of the Dynamics and Design Conference 2007, No. 07-8(2007),CD-ROM (Paper No. 426) ,pp.1-6 (in Japanese).

Kimura, H. and Nakagawa, T., Vibration analysis of elevator rope with vibration suppressor, Transactions of the Japan Society of Mechanical Engineers, Series C, Vol. 71, No. 702 (2005), pp. 442-447 (in Japanese).

Kimura, H., Iijima, T., Matsuo, S. and Fujita, Y., Vibration analysis of elevator rope (Comparison between experimental results and calculated results), Transactions of the Japan Society of Mechanical Engineers, Series C, Vol. 74, No. 737 (2008), pp. 31-36 (in Japanese).

Nakagawa, J. and Arai., S., Damping of elevator rope swing by resting movement of compensation sheave, Elevator, Escalator and Amusement Rides Conference, No. 11-94 (2012), pp. 23-26 (in Japanese).

Otsuki, M., Yoshida, K., Nagata, K., Kimura, H. and Nakagawa, T., Vibration control for rope-sway of elevator of high-rise building (Application of nonstationary optimal control to time-varying flexible system), Transactions of the Japan Society of Mechanical Engineers, Series C, Vol. 68, No. 676 (2002), pp. 3589-3596 (in Japanese).

Seto, K., Dynamic vibration absorber and its applications (2010), pp.1-56, Corona Publishing Co., LTD (in Japanese).

Watanabe, S., Nishida, T. and Yamane, T., Elevator rope dynamics during long-period ground motion, Elevator, Escalator and Amusement Rides Conference, No. 06-67 (2007), pp. 15-18 (in Japanese). 